\title{
Fatores determinantes da produção habitacional de interesse social em áreas centrais metropolitanas em tempos de financeirização
}

Determinants of social housing production in downtown metropolitan areas in times of financialization

Ulisses Demarchi Silva Terra [I] Ricardo de Sousa Moretti [II]

\section{Resumo}

Este artigo discute, a partir de entrevistas realizadas junto a uma série de especialistas, quais os principais fatores que viabilizam/inviabilizam a produção de habitação de interesse social nas áreas centrais dos grandes centros urbanos. A influência do processo de transformação da propriedade imobiliária em ativo financeiro global e a análise da produção habitacional realizada pelo Estado em metrópoles brasileiras são referências para uma reflexão ampliada sobre o tema. A cidade de São Paulo é objeto principal das discussões, pesquisas e dados apresentados neste trabalho. Ao final do artigo é apresentada uma série de apontamentos no intuito de contribuir para o amadurecimento do debate sobre o desenvolvimento de políticas habitacionais para as áreas centrais das metrópoles brasileiras.

Palavras-chave: habitação de interesse social; área central; direito à moradia; financeirização imobiliária; São Paulo.

\begin{abstract}
This article discusses, based on interviews with several specialists, the main factors that enable/hinder the production of social housing in downtown areas of large urban centers. The transformation process of real estate into global financial assets and the analysis of housing production by the State in Brazilian metropolises are references for an extended reflection on the theme. The city of São Paulo is the main object of the discussions, researches and data presented in this work. At the end of the article, some notes are presented in order to contribute to the maturation of the debate on the development of housing policies for downtown areas of Brazilian metropolises.
\end{abstract}

Keywords: social housing; downtown area; right to housing; real estate financialization; São Paulo. 


\section{Introdução: notas sobre a moradia em tempos financeirização}

Em um cenário de escalada dos processos de transformação da propriedade imobiliária em ativo financeiro global, o acesso à moradia digna é um enorme desafio para a maior parte da população que vive nos grandes centros urbanos. Para a economista Pettifor (2018), mais do que uma relação entre oferta e demanda, a propriedade habitacional tornou-se uma questão de investimento ou de especulação imobiliária. Para a socióloga Sassen (2017, p. 122), a novidade desse recente processo de financeirização não se dá em função das transações internacionais com valores vultosos para a aquisição de propriedades imobiliárias em cidades que funcionam como centros internacionais, a novidade se dá em função do uso das propriedades, ou melhor, seu não uso: muitos dos edifícios comercializados são subutilizados. Em Londres, entre os anos de 2008 e 2013, grandes investidores gastaram mais de 100 bilhões de libras na aquisição de imóveis (Crerar e Prynn, 2015), muitos dos quais com luxuosas propriedades localizadas nas áreas mais caras da cidade e que são utilizadas por seus proprietários somente algumas semanas do ano (Osborne e Rawlinson, 2017). Em São Paulo alguns distritos em áreas consolidadas da cidade receberam, na década de 2000, mais lançamentos imobiliários do que o número de moradores. ${ }^{1}$ Frutos da especulação imobiliária produzem o que Nakano (2015, p. 230) chamou de "cidade oca": áreas da cidade formadas por empreendimentos que expandem a área construída residencial sem promover o adensamento demográfico.

A transformação progressiva de propriedades imobiliárias em ativos que podem ser vendidos ou comprados em diversos mercados do mundo sem a preocupação com a existência do edifício real ganha escala até então inimagináveis. Estima-se ${ }^{2}$ que os ativos imobiliários globais totalizem o valor de US\$217 trilhões entre propriedades comerciais, residenciais, áreas florestais e agrícolas. Desses ativos, 75\% do valor, ou US\$162 trilhões, referem-se a propriedades residenciais. Ainda que a maior parte das propriedades do mundo seja modesta e não tenha sido financeirizada, são cada vez mais notáveis os impactos desse processo de globalização da propriedade imobiliária na vida das metrópoles.

Como coloca a arquiteta urbanista Raquel Rolnik (2015), a disseminação de um modelo hegemônico baseado na propriedade privada individual, na qual a moradia é um produto e os governos meros facilitadores da gestão habitacional, aumenta as desigualdades no território. Os avanços da visão do setor de moradias como um mercado, preconizada pelo Banco Mundial (1993), sobrepuseram a compreensão da moradia como direito, e o aprimoramento dos mecanismos de investimento do capital financeiro internacional no setor imobiliário provocou a sobrevalorização dos imóveis no mundo e fragilizou a segurança de posse de seus moradores. Entre 1997 e 2004, o preço médio para a aquisição de residências cresceu 65\% nos Estados Unidos, 149\% na Espanha, $139 \%$ no Reino Unido, $187 \%$ na Irlanda e 112\% Austrália (Rolnik, 2015, p. 39). Entre os anos de 2009 e 2013, segundo dados do Bank 
for International Settlements, ${ }^{3}$ o Brasil liderou o ranking mundial de valorização de imóveis residenciais com o aumento de $121,6 \%$ do seu preço médio (Nakagawa, 2014).

\section{A recente produção habitacional de interesse social em metrópoles brasileiras}

A conquista do direito à moradia pouco avançou nos últimos anos nas jovens metrópoles dos países subdesenvolvidos. 0 direito à cidade tornou-se um conceito disperso, inteligível apenas em sua ausência, por aqueles que se perdem diariamente em viagens intermitentes entre o local do morar e o restante da vida urbana. As metrópoles contemporâneas tornaram-se local privilegiado das contradições urbanas, concentram as maiores riquezas produzidas pelo ser humano e também as situações de maior pobreza. No Brasil, as dez maiores metrópoles concentram $41,6 \%$ do Produto Interno Bruto ${ }^{4}$ e também as situações de moradias mais precárias. Utilizando dados do Censo de 2010, pesquisadores concluíram que a subnormalidade ${ }^{5}$ é um fenômeno metropolitano (Nadalin, Krause, Lima Neto, 2016, p. 78): $74,83 \%$ dos 11,4 milhões de habitantes que viviam em aglomerados subnormais no Brasil estavam em regiões metropolitanas.

Locais privilegiados quanto à disponibilidade de infraestrutura, empregos, serviços e outras características que possibilitam a efetivação do direito à moradia adequada, as áreas centrais das metrópoles brasileiras são inacessíveis, via mercado imobiliário formal, à grande parte da população brasileira. A histórica concentração de terras que formaram as cidades brasileiras - na cidade de São Paulo, por exemplo, $1 \%$ da população concentra $45 \%$ do valor dos imóveis ${ }^{6}$ - e este processo global de transformação da propriedade imobiliária em ativo financeiro contribuem para tornar os imóveis ainda mais caros e menos acessíveis para a população de baixa renda. A produção habitacional via Estado e as políticas habitacionais poderiam representar uma solução a esse problema, porém a iniciativa pública de promoção de projetos habitacionais para a população de baixa renda ocorre em grande parte, mesmo quando há recursos significativos, na periferia das metrópoles. Os projetos para áreas centrais possuem escala pouco expressiva e são majoritariamente sob a forma de propriedade privada individual, o que representa restrições quanto à sustentabilidade da política habitacional e à garantia de permanência das famílias residentes.

Nos últimos anos, um dos poucos programas habitacionais que conseguiu produzir unidades em áreas centrais foi o Programa de Arrendamento Residencial (PAR) do governo federal. Entre os anos de 1999 e 2005, foram produzidas, no âmbito do Programa, 177.150 unidades habitacionais, das quais 1.425 unidades em áreas centrais de regiões metropolitanas (Bonates, 2009, p. 114). Entre as cidades que desenvolveram projetos em áreas centrais através do PAR (Tabela 1), destacam-se Porto Alegre e São Paulo, nas quais, através de parcerias com os governos locais, foi possível desenvolver empreendimentos de maior porte e contratar um maior número de unidades (ibid.). 

Tabela 1 - Financiamentos para reabilitação habitacional
no âmbito do PAR (1999-2005)

\begin{tabular}{l|c|c|c}
\hline \multicolumn{1}{c|}{ Cidade } & Operações contratadas & $\begin{array}{c}\mathbf{N}^{\circ} \text { de unidades } \\
\text { contratadas }\end{array}$ & $\begin{array}{c}\text { Média de unidades } \\
\text { por edifício }\end{array}$ \\
\hline São Paulo & 7 & 709 & 101 \\
Rio de Janeiro & 6 & 70 & 11 \\
Salvador & 5 & 41 & 8 \\
Porto Alegre & 4 & 309 & 77 \\
São Luís & 1 & 16 & 16 \\
Peloras & 1 & 140 & 140 \\
Belem & 1 & 66 & 66 \\
Recife & 1 & 56 & 56 \\
\hline Total & 26 & 1.425 & 54 \\
\hline
\end{tabular}

Fonte: Bonates (2009, p. 114).

No ano de 2009, mesmo com o aporte financeiro vultoso no lançamento do Programa Minha Casa Minha Vida (PMCMV), não houve mudança no caráter periférico da produção habitacional pública nas metrópoles brasileiras. Na cidade do Rio de Janeiro, das cerca de 33 mil unidades habitacionais contratadas para famílias da faixa $1^{7}$ do Programa MCMV até 0 ano de 2014, 53\% estão localizadas na zona oeste da cidade, muito distante da região central e da zona sul, onde está concentrada a maior parte da oferta de empregos formais e de serviços (Linke et al., 2016, p. 273). Estudo ampliado (Lima Neto, Krause e Furtado, 2015) sobre a localização da produção habitacional para beneficiários da faixa 1 do Programa MCMV em regiões metropolitanas revela que, mesmo com o aumento significativo no valor de referência máximo para a construção das unidades habitacionais, realizado na segunda fase do programa, ${ }^{8}$ houve um aumento do número de empreendimentos implantados em áreas ainda mais distantes da área central do núcleo metropolitano (Tabela 2).

0 estudo revela, ainda, que a maior parte da produção do Programa na RM de Belém foi realizada a distâncias superiores a 20 quilômetros do centro (8.129 U.H.) e em distâncias entre 15 e 20 quilômetros (6.170 U.H.). Quanto à RM de Fortaleza, existe uma produção habitacional intensa na faixa entre 10 e 20 quilômetros do centro, revelando uma das menores médias de distância dos empreendimentos em relação ao centro entre as metrópoles analisadas (ibid., p. 24). Em Belo Horizonte, à exceção de dois empreendimentos produzidos mais próximos da área central, todos os demais estão a mais de 10 quilômetros do núcleo da metrópole, com alguns implantados a quase 60 quilômetros de distância (ibid., p. 29). Em Goiânia, ainda que a maior parte das unidades habitacionais contratadas $(34,72 \%$ do total) esteja 
Tabela 2 - Distância dos empreendimentos MCMV-FAR em relação ao centro das regiões metropolitanas

\begin{tabular}{l|c|c|c|c|c|c}
\hline \multicolumn{1}{c|}{ RMs } & Período & Média & Desvio-padrão & Início & Fim & $\begin{array}{c}\text { Quantidade de } \\
\text { empreendimentos }\end{array}$ \\
\hline \multirow{2}{*}{ Belém } & 1 & 21,34 & 6,41 & ago/2009 & dez/2010 & 11 \\
& 2 & 24,30 & 12,04 & nov/2011 & jun/2013 & 14 \\
\hline \multirow{2}{*}{ Fortaleza } & 1 & 18,70 & 12,41 & nov/2009 & dez/2010 & 18 \\
& 2 & 27,65 & 18,55 & dez/2011 & jun/2013 & 22 \\
\hline \multirow{2}{*}{ Belo Horizonte } & 1 & 28,35 & 11,19 & dez/2010 & dez/2010 & 17 \\
\hline \multirow{2}{*}{ Porto Alegre } & 2 & 27,14 & 16,53 & jun/2013 & jun/2013 & 13 \\
\hline \multirow{2}{*}{ Goiânia } & 2 & 25,10 & 15,26 & ago/2009 & dez/2010 & 22 \\
\hline
\end{tabular}

Fonte: Lima Neto, Krause, Furtado (2015, p. 19).

localizada no município-sede da metrópole, estes estão distantes da área central (ibid., p. 32). Já, na RM de Porto Alegre, mesmo apresentando valores elevados de distância média dos empreendimentos habitacionais em relação à região central, parece haver uma distribuição mais equilibrada entre as regiões com maior déficit habitacional e a localização dos empreendimentos promovidos no âmbito do PMCMV (ibid., p. 30).

Estudo recente sobre a localização territorial da produção habitacional na metrópole paulistana (Marques e Rodrigues, 2013), realizado com base nos 557 empreendimentos contratados pelo Programa MCMV até junho de 2013, revela que os empreendimentos para faixa um (34,1\% das unidades contratadas) distam ${ }^{9}$ em média $26 \mathrm{~km}$ do centro da cidade e $28,2 \mathrm{~km}$ da região da Berrini. ${ }^{10}$ Nos empreendimentos de maior faixa de renda, a distância dessas duas centralidades diminui: são 21,3km e 23,3km de distância, respectivamente, da Sé e da Berrini, para os empreendimentos faixa dois (38,5\% das unidades contratadas), e $18,7 \mathrm{~km}$ e 19,5km, respectivamente, de distância para os empreendimentos da faixa três $(27,4 \%$ das unidades contratadas). 0 estudo revela, ainda, a distância média de empreendimentos realizados pela Companhia de Desenvolvimento Habitacional e Urbano (CDHU), no âmbito estadual e da Companhia Metropolitana de Habitação (Cohab) em âmbito municipal. Os empreendimentos da CDHU distam, em média, 23,3km e $25,8 \mathrm{~km}$ da Sé e da Berrini, e os da Cohab, $18,4 \mathrm{~km}$ e $22,2 \mathrm{~km}$ das respectivas localidades (ibid., p. 169). Como podemos observar no Mapa 1, os empreendimentos para baixa renda possuem um padrão periférico de inserção na metrópole paulistana com número extremamente reduzido de projetos em áreas centrais. 
Mapa 1 - Localização dos empreendimentos Faixa um do PMCMV na RMSP

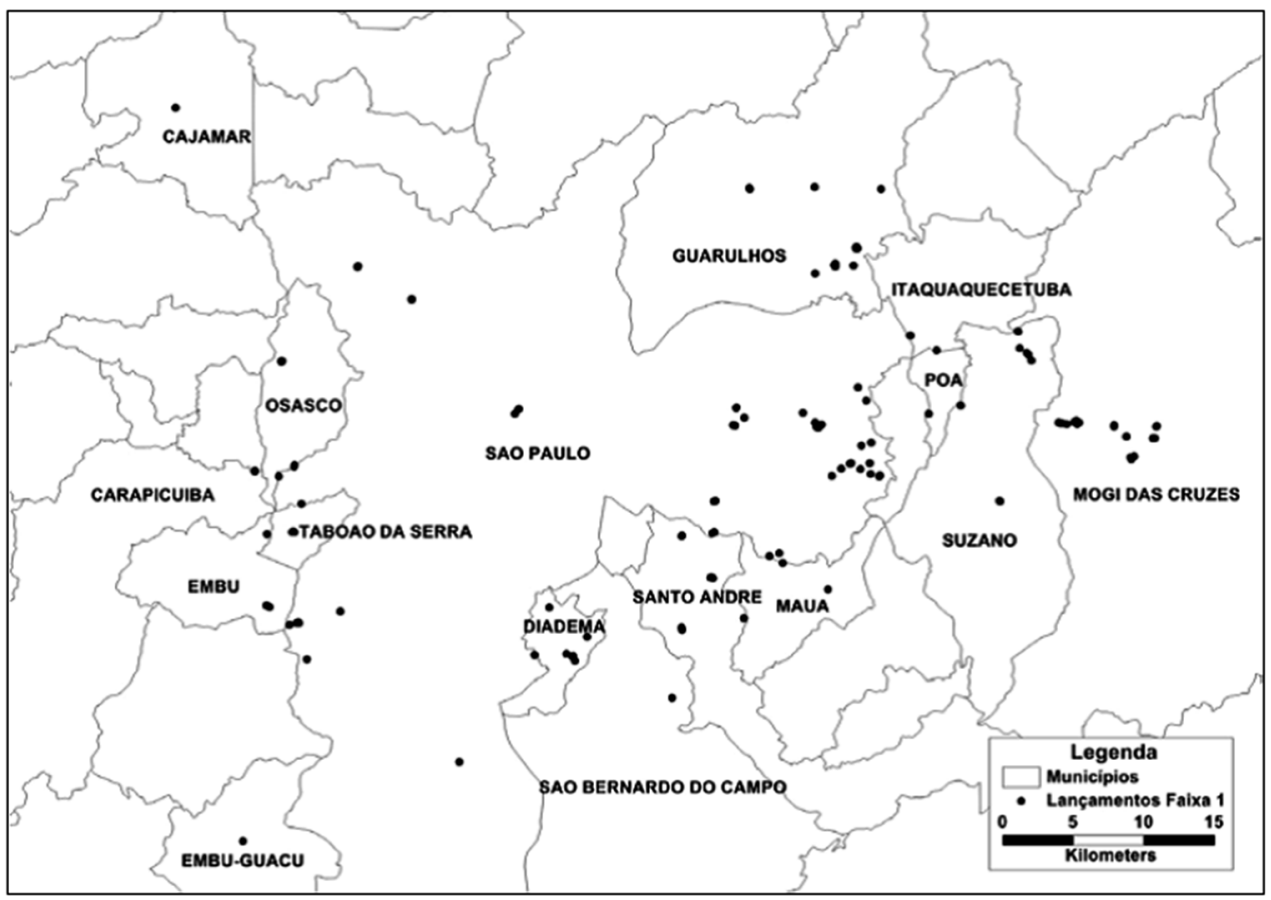

Fonte: Marques e Rodrigues (2013, p. 166).

Dados atualizados ${ }^{11}$ sobre a produção de habitação social na área central da cidade de São Paulo, baseados em inventários realizados por Sanches (2015) e por Barbosa (2014), revelam que, entre 1990 e janeiro de 2018, foram concluídas 4.468 unidades habitacionais na região, sendo 1.340 unidades produzidas por programas municipais, 2.197 unidades por programas estaduais e 931 unidades por programas federais. Vale ressaltar que alguns dos empreendimentos, como o recém-inaugurado edifício Dandara, situado na avenida Ipiranga, foram viabilizados através da articulação de programas e subsídios das três esferas de governo. Temos, assim, que nos últimos 28 anos foram produzidas, em média, 160 unidades habitacionais por ano na região central, número bastante baixo se pensamos o centro como local privilegiado para a efetivação do direito à moradia em uma região metropolitana com déficit habitacional estimado ${ }^{12} \mathrm{em} 561.307$ domicílios (Ipea, 2013) e cuja cidade-sede possui 1,2 milhão de famílias vivendo em situação precária de moradia (Pina, 2018). 


\section{Fatores que (in)viabilizam a produção de habitação social no centro da metrópole paulistana}

A complexidade do tema habitacional e do direito à moradia na metrópole envolve uma diversidade de fatores, contextos, atores e momentos. No intuito de enriquecer essa discussão, vários especialistas de diferentes formações e áreas de atuação foram entrevistados. ${ }^{13}$ Os principais elementos dessas entrevistas são colocados em discussão, tendo como referência a metrópole paulistana e uma série de pesquisas, livros, reportagens e dados sobre 0 assunto. 0 objetivo aqui é ampliar a reflexão sobre as principais dificuldades para se viabilizarem projetos de habitação de interesse social em áreas centrais e apresentar considerações que contribuam para o amadurecimento do tema no desenvolvimento de políticas públicas nacionais.

0 custo dos imóveis - terrenos e edifícios - foi um dos principais fatores, e talvez o de maior discussão, nas entrevistas sobre a questão da viabilidade de projetos de habitação social na área central da cidade. Para Renata Milanesi, arquiteta da Cohab-SP atuante em projetos para as áreas centrais, o alto custo dos imóveis é um dos principais fatores a dificultar a viabilização dos projetos: "Quando você começa a falar em um projeto e parte de uma desapropriação em que o custo do imóvel antes das obras supera $100 \mathrm{mil}$ reais por unidade habitacional aí então o projeto para". Para Débora Sanches o alto custo dos imóveis acaba por interferir, inclusive, na arquitetura e nas dimensões das unidades habitacionais: "No Par Reforma, ${ }^{14}$ os valores máximos para viabilizar uma U.H. eram muito pequenos, assim, tiveram que reduzir muito $o$ tamanho do imóvel para se adequar à verba existente". Para o professor Joel Felipe, com ampla experiência em obras públicas e projetos habitacionais populares, o preço da terra é resultado de processos especulativos e de sucessivas extensões para a periferia das cidades, configurando-se como um dos principais fatores que inviabilizam a promoção de habitação social na área central.

Para Claudio Bernardes, ex-presidente do Secovi ${ }^{15}$ e presidente da Ingai Incorporadora S/A, envolvido em projetos de reabilitação de edifícios na área central da cidade de São Paulo desde o final da década de 1090, a terra é um dos principais fatores para se viabilizar a produção de habitação social na área central, mas não tanto pelo custo, que em sua visão é mais convidativo que em algumas outras áreas da cidade, e sim pela falta de terrenos disponíveis. É interessante destacar, aqui, a necessidade de estabelecermos certa dissociação entre a questão do custo da terra e do custo das edificações existentes. Isto porque as áreas centrais dos grandes centros urbanos apresentam grande número de edifícios vazios ou subutilizados, porém poucos terrenos vagos disponíveis. Dados do Censo Demográfico (IBGE, 2012) revelam que o centro ${ }^{16}$ da cidade de São Paulo possuía 431.106 habitantes em 2010 e um total de 208.643 domicílios particulares permanentes, dos quais $9,5 \%$ ou 19.744 estavam vagos. No final do século XX, houve uma redução de quase $30 \%$ da população na região que passou de 526.170 habitantes, em 1980, para 373.914 habitantes nos anos 2000 (IBGE apud Prefeitura de São Paulo, 2009). Porém, na década de 
2000, o centro voltou a atrair moradores com um crescimento populacional de 15,3\%.

A questão da vacância é outro elemento com mudanças significativas na última década. Do ano 2000 para o ano de 2010, mesmo com um aumento de 10,7\% no total de domicílios na cidade, a taxa média de vacância no município baixou de $11,8 \%$ para $7,5 \%$. As maiores quedas, na década de 2000, ocorreram nos distritos da região central, onde a taxa de vacância passou em média de $24,7 \%$ para 9,5\% (IBGE, 2003 e 2012). Nos distritos da Sé, República e Santa Cecília, as taxas caíram de maneira ainda mais significativa, passando respectivamente de $39,8 \%$ para $11,7 \%$, de $33,7 \%$ para $11,6 \%$ e de $24,2 \%$ para $7,5 \%$ (ibid.). Os valores ainda são significativamente superiores à faixa entre $5 \%$ e $7 \%$ considerada aceitável para a dinâmica imobiliária, segundo estudos realizados por especialistas (Bomfim, 2004). São diversos os elementos e as justificativas para a queda significativa do número de imóveis vazios na cidade de São Paulo como um todo e de sua área central em específico. Nadalin (2010) desenvolve tese na qual procura integrar diferentes áreas de estudo para a compreensão da questão da vacância no âmbito dos mercados imobiliários. Dentre os principais elementos, Nadalin destaca: a questão da localidade, tanto devido aos custos de deslocamento quanto à disponibilidade de serviços e de infraestrutura; as características físicas das unidades habitacionais; a questão da oferta e da demanda do mercado imobiliário; e as mudanças nas atividades macroeconômicas.

Para o arquiteto Renato Cymbalista, a maior queda nas taxas de vacância na área central da cidade de São Paulo se deve ao fato de esta ser uma região na qual havia mais imóveis desocupados e pela qual o mercado imobiliário voltou a se interessar (Felitti e Correa, 2015). Para o economista Paulo Sandroni (ibid.), a melhora do nível de emprego, a valorização salarial e as políticas sociais são um dos principais responsáveis pela redução da taxa de vacância. De fato, o fator econômico provocou uma nova dinâmica no mercado habitacional brasileiro com possíveis reflexos nas taxas de vacância habitacional. Shimbo (2013) destaca que 0 aquecimento imobiliário ocorrido no Brasil após o ano de 2006 abrangeu uma nova faixa de consumidores e áreas no território até então pouco valorizada pelo mercado. 0 aquecimento deu-se em grande parte pelo vultoso aumento de recursos de fundos públicos e semipúblicos para os financiamentos habitacionais em nível federal e pelo lançamento do PMCMV, com a produção massiva de unidades habitacionais. 0 valor total contratado pelo Sistema Financeiro Habitacional $(\mathrm{SFH})^{17}$ saltou de aproximadamente cinco bilhões de reais no início de 2003 para mais de quarenta bilhões no ano de 2008 (ibid.).

Para a professora Regina Meyer, o fenômeno é explicado em parte pela mudança do poder público para a área central da cidade, a partir do ano de 2000, trazendo quantidade expressiva de funcionários de órgãos administrativos para a região (Felitti e Correa, 2015). Para Vanessa Nadalin, a queda da vacância no centro pode ser também explicada pela questão da piora do trânsito na cidade e pela facilidade de mobilidade da região central (ibid.). Uma análise mais ampla sobre o fato leva-nos a notar que a redução da vacância habitacional atingiu o município como um todo e não só a região central. Dados do Censo Demográfico (IBGE, 2003) revelam que, no ano de 2000, 
havia 420.327 imóveis vazios no município, sendo 8,23\% destes, ou 34.592, na área central. Já, no ano de 2010 (IBGE, 2012), o número de imóveis vazios na cidade caiu para 293.621, sendo $6,72 \%$ destes, ou 19.744 unidades, no centro. Se analisarmos dados do Brasil como um todo, constatamos que, entre os anos de 2000 e 2010, também houve queda no percentual de domicílios particulares vagos. Ainda que esse número tenha aumentado, de 6.029.756 no ano 2000 para 6.097.778 em 2010, o percentual dos domicílios particulares nessa categoria para o País caiu de 11,11\%, em 2000, para 9,04\% em 2010 (IBGE, 2003 e 2012).

Outro elemento relevante, nesta análise, é a recentemente proliferação de imóveis de dimensões super-reduzidas ${ }^{18}$ na área central da cidade com apartamentos de até $10 \mathrm{~m}^{2}$. Para o professor João Lima Júnior, quanto menor for o apartamento, mais ele atrairá investidores, mesmo que o valor do $\mathrm{m}^{2}$ seja superior em relação ao de outras unidades (Felitti e Correa, 2015). 0 imóvel, nesse caso, é mais um investimento do proprietário do que uma aquisição para fins de moradia própria.

Quanto à disponibilidade de terrenos, dados do ano de 2015, fornecidos pela Secretaria Municipal de Desenvolvimento Urbano do município, ${ }^{19}$ revelam que 3,26\% da área de terrenos dos imóveis cadastrados no centro de São Paulo estavam vagos. 0 número é relativamente baixo se comparado aos $13,17 \%$ de área total de terrenos vagos do município como um todo, mas é bastante significativo em termos quantitativos: são 1.643 imóveis com um total de 581.174 metros quadrados de terreno vago. Para Claudio Bernardes, o subsídio do Programa Minha Casa Minha Vida ${ }^{20}$ do governo federal somado ao subsídio do Programa Casa
Paulista $^{21}$ do governo do estado de São Paulo são suficientes para construir as unidades habitacionais, o problema é o custo da terra. De fato, se consideramos o preço médio do metro quadrado dos imóveis nos diversos bairros da cidade, verificaremos que a região central está longe de ser a mais cara, porém, tão pouco de ser a mais barata. Dados de outubro de $2016^{22}$ revelam que o preço médio do metro quadrado de um apartamento em bairros do quadrante sudoeste, ${ }^{23}$ como Vila Nova Conceição e Jardim Europa, é de 12 mil reais, enquanto nos bairros centrais, da Sé e República, é de 6,3 mil reais e, em bairros periféricos, como Cidade Tiradentes, na extrema zona leste, e Capão Redondo, na zona sul, são respectivamente de 2,5 mil e 3,9 mil reais. Esses valores revelam um mapa de preço de imóveis na cidade bastante desigual (Figura 1).

Para Joel Felipe, é barato para a sociedade produzir novas unidades ou reabilitar edifícios nas áreas centrais das cidades. Para 0 arquiteto urbanista, há um grande custo social, ambiental e financeiro, na forma de impostos e taxas, que é pago por toda sociedade e que deve ser considerado, quando se produz distante da área central. São os custos dos deslocamentos pendulares, da manutenção da malha viária e de subsídios ao transporte público, do congestionamento, da poluição, do aumento das áreas impermeabilizadas, do espraiamento das cidades, das despesas com saúde, etc., que são muitas vezes desconsiderados quando da formulação da política habitacional.

Na prática, porém, parece faltar recursos ou vontade política para viabilizar projetos habitacionais na área central em larga escala. No ano de 2009, a Prefeitura Municipal contratou a Fundação para a Pesquisa Ambiental 
Figura 1 - Mapa de valor de $\mathrm{R} \$ / \mathrm{m}^{2}$ da cidade de São Paulo

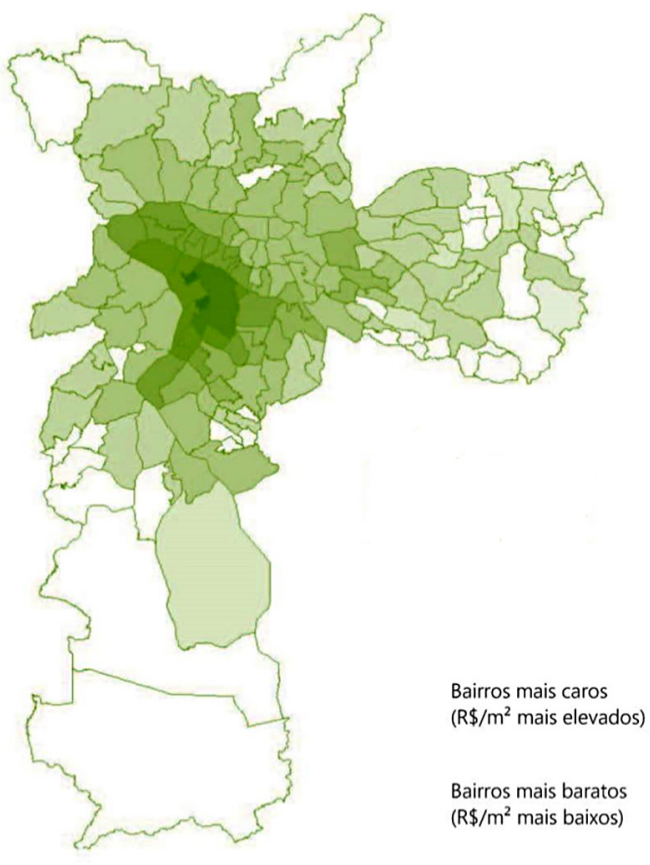

Fonte: Fipezap (2017).

(Fupam) para a realização de um amplo diagnóstico sobre os imóveis da área central. $\mathrm{A}$ Fupam, conjuntamente com a prefeitura municipal, desenvolveu uma série de estudos preliminares para a reabilitação de 52 imóveis. Com os estudos em mãos, a prefeitura lançou, em fevereiro de 2010, o programa Renova Centro com a previsão de investimentos da ordem de 400 milhões de reais, e a meta de viabilizar 2.500 unidades habitacionais. 0 Renova Centro, nas palavras do secretário de habitação municipal à época, seria "[...] o maior programa de reforma de prédios para fins habitacionais, sem precedentes na história do país, pela escala e compromissos assumidos" (Leite e Gonçalves, 2010). Renata Milanesi relata que os 52 imóveis do estudo foram decretados como de interesse social sem que, no entanto, houvesse recurso para compra. Passados quase oito anos do programa, apenas um empreendimento foi viabilizado. Para Alejandra Devecchi, que foi coordenadora do talvez maior e mais polêmico projeto para a área central - o Projeto Nova Luz-, a requalificação na área central não acontece porque não é possível mobilizar todos os recursos necessários. 


\section{Habitação social em área central para além dos custos iniciais}

Os altos custos relativos à aquisição de terrenos ou de edifícios para reforma em áreas centrais é questão-chave para as políticas habitacionais, mas não é a única. As discussões sobre o tema envolvem ainda uma complexa trama de fatores, dentre os quais destacaremos: a questão das formas de posse e propriedade; 0 desenvolvimento de políticas públicas direcionadas e da necessidade de vontade política; a questão dos processos de desapropriação e das longas cadeias dominiais; as dificuldades e a falta de conhecimento para a reabilitação de edifícios; e o trabalho social e a gestão condominial dos edifícios.

\section{Forma de propriedade e posse}

Para Helena M. B. Silva, referência em pesquisas sobre áreas centrais, a questão da forma de propriedade é um dos elementos principais que se deveria avaliar em programas habitacionais em áreas centrais. Helena questiona se a propriedade é de fato fundamental para as políticas habitacionais e, de maneira crítica, cita o fato de o programa Minha Casa Minha Vida não ter colocado em pauta a questão da propriedade e de ser mais uma política de alto subsídio para a produção habitacional na periferia. Especialistas ressaltam que a produção massiva de moradia social com finalidade de compra e na forma de propriedade individual acaba por dinamizar o mercado imobiliário, dificultando o acesso aos imóveis pela população de baixa renda e beneficiando os investidores e os grandes proprietários (Kohara, Comaru e Ferro, 2015).

Para a arquiteta Renata Milanesi, na promoção de habitação social em áreas centrais, deve ser pensada outra relação entre direito de posse e propriedade. Milanesi afirma que as relações de uso e posse deveriam ter maior importância do que a propriedade: "Um apartamento no centro vale 250/350 mil reais. Se o morador de baixa renda, entre 0 e 3 salários, tiver a propriedade, ele provavelmente irá vender". Helena M. B. Silva sugere um programa massivo de locação social, maneira pela qual teríamos uma grande evolução das políticas habitacionais para as áreas centrais. São Paulo possui, desde 2002, um programa de locação social com 903 U.H. na área central do município. 0 programa, que precisa ser ampliado, ainda que considerado por especialistas como um grande avanço da política de habitação social, possui uma série de gargalos estruturais que necessitam ser melhorados (Gatti, 2015).

Em publicação de avaliação do PMCMV, pesquisadores enfatizam que uma política habitacional de abrangência nacional não pode ter como únicas formas de atuação a construção e a transferência de novas unidades habitacionais. Para eles, a questão da forma de propriedade deve ser parte do amadurecimento do debate que desloca a questão do déficit habitacional para a questão das necessidades habitacionais:

0 direito à moradia não pode ser reduzido ao direito à propriedade individual isto é, à casa própria. Essa questão se apresenta como um grande entrave por não permitir que o sistema funcione para atender as necessidades de moradia. 
Vários fatores concorrem para isto, embora modalidades como a propriedade coletiva e a locação/arrendamento assinalem potencial para facilitar tal rearranjo. Não surpreende, portanto, que a "solução" físico-espacial dos empreendimentos do PMCMV tenha nascido condenada ao fracasso arquitetônico-urbanístico, a despeito das inúmeras críticas que já tenham sido realizadas a esse tipo de solução. (Santo Amore, Shimbo e Rufino, 2015, p. 420)

\section{Desapropriação e cadeias dominiais}

Outro fator considerado determinante na promoção da habitação social na área central é a complexidade das cadeias dominiais. ${ }^{24}$ Para a arquiteta Alejandra Devecchi, que esteve diretamente envolvida em diferentes programas de reabilitação da área central da cidade de São Paulo, a complexidade das cadeias dominiais é um dos principais fatores que inviabiliza a produção de habitação social. Devecchi coloca que $60 \%$ dos imóveis possuem matrícula única no centro, o que simplifica o processo, porém os imóveis possuem muitos donos e muitos herdeiros "[...] são 20, 30 pessoas donas de um mesmo imóvel", comenta.

Além disso, na visão da arquiteta Renata Milanesi, há um aspecto favorável à produção de habitação social pelo município nessas situações, pois a prefeitura, em um processo de desapropriação, possui certas facilidades que o proprietário particular não possui. Para ela, casos de inventário ou dívida de IPTU podem ser mais facilmente solucionados: "A desapropriação 'limpa' a matrícula do imóvel. A prefeitura consegue regularizar o imóvel porque pode criar um novo registro. 0 proprietário deixa de ter um custo alto e trabalhoso caso fosse regularizar o imóvel como particular".

Para Débora Sanches, para além das cadeias dominiais, um dos principais fatores na viabilidade dos projetos habitacionais na área central é a resolução de toda a documentação jurídica necessária. Para o professor Joel Felipe, as questões relativas aos processos de aquisição e desapropriação de edificações e terrenos na área central podem ser mais trabalhosas e exigir maior negociação, mas são solucionáveis com uma boa gestão e uma legislação adequada. Em sua visão, as leis de dação em pagamento, por exemplo, se utilizadas com competência, poderiam agilizar os processos de negociação de proprietários com dívidas municipais. 0 instrumento citado poderia muito bem ser aplicado no centro de São Paulo onde, como lembra Débora Sanches, existem casos de dívidas de IPTU maiores do que o valor venal do imóvel. Para Joel Felipe, com tantas possibilidades fundiárias e com o tamanho estoque de imóveis disponíveis na cidade, as dificuldades relacionadas à questão de documentação são uma questão jurídica de importância menor para a política habitacional.

Para o advogado da União dos Movimentos de Moradia (UMM), Benedito Barbosa, são os processos de desapropriação que travam a política habitacional no centro. Para ele, as desapropriações são muito caras porque os governos e o judiciário não consideram para fins de desapropriação uma série de variáveis, como o fato de o imóvel estar ocupado, de descumprir a função social da propriedade, de ter um uso habitacional social. 0 juiz, conforme relatado por Barbosa, aplica invariavelmente o preço do mercado. Como exemplo de controverso processo de desapropriação, 
o autor cita o emblemático caso da Ocupação Mauá. No início do processo de negociação pelo movimento junto ao proprietário, no final da década de 2000, o imóvel custava 2 miIhões de reais. Em 2013, a prefeitura decretou o imóvel como de interesse social e o avaliou em 13 milhões de reais. Em 2014 a prefeitura depositou R\$11 milhões em juízo para a aquisição do imóvel. Os proprietários entraram com recursos, exigiram nova perícia, e o valor subiu para 23 milhões de reais. Em novembro de 2017, o imóvel de aproximadamente $5.600 \mathrm{~m}^{2}$, onde funcionou um hotel desativado na década de 1970 (Souza, 2017), teve a proposta de cerca de 20 milhões de reais aceita pelos proprietários (Adorno, 2017). Por fim o imóvel, que ficou desocupado por mais de 20 anos, com uma grande dívida de IPTU e em péssimas condições de manutenção, será adquirido pela prefeitura por esse altíssimo valor. A reabilitação do imóvel deve atender cerca de 160 famílias com um custo de desapropriação de cerca de 125 mil reais por unidade habitacional, valor superior aos 100 mil reais relatados por Renata Milanesi como limite, em termos da dificuldade para viabilizar os projetos habitacionais na área central.

Em estudo específico sobre habitação social em área centrais, Helena M. B. Silva, ex-coordenadora do programa Morar no Centro, ${ }^{25}$ afirma que a "justa indenização", determinada pela Constituição de 1988 (parágrafo terceiro do art. 182), se configura na prática com valores ainda superiores ao valor de mercado (Silva, 2007, p. 14). Para ela, é clara a desvantagem do setor público diante do setor privado na oportunidade de aquisição de imóveis. Cita, como exemplo, a utilização da permuta, na qual o valor do terreno é trocado por unidades do futuro empreendimento, que é prática amplamente utilizada pelas incorporadoras, mas vedada aos agentes do poder público. No estudo, faz menção ao projeto do edifício Ana Cintra, na região central, onde o processo judicial fez triplicar o preço do imóvel. Ainda assim, Silva pondera que "[...] a desapropriação seria o mecanismo adequado para resolver questões de espólios, proprietários ausentes, dívidas, etc." (ibid.).

Embora se tenha utilizado a desapro-
priação em vários programas, existe uma
grande diferença entre as que se con-
cluem por acordo e as que resultam de
condenação judicial. Quanto ao custo do
imóvel, ter a desapropriação concluída ou
não faz toda a diferença, pois nos proces-
sos judiciais não existe nenhum controle
sobre os valores a pagar. (lbid., p. 41)

Infelizmente os altos custos e os muitas vezes escusos processos de desapropriação são, de longa data, grandes limitantes para a implementação de diversas políticas públicas. Alguns processos de desapropriação de terras das décadas de 1980 e 1990 no estado de São Paulo revelavam casos de indenizações equivalentes "[...] ao orçamento geral de um ou mais mandatos políticos de uma instância de governo" (Maricato et al., 2001). Para o advogado da UMM, o judiciário e os cartórios deveriam ter outro posicionamento para facilitar os processos de desapropriação. ${ }^{26} \mathrm{~A}$ abertura de uma nova matrícula e a possibilidade de se depositar em juízo o valor do imóvel até que houvesse a resolução de todos os problemas de matrícula, herdeiros, etc., seriam uma saída na visão de Barbosa. 


\section{Reabilitação de edifícios}

Enquanto no Brasil a reabilitação de edifícios passou a ser pauta mais frequente nas discussões do setor da construção, a partir dos anos 2000, na Europa a atividade possui expressiva envergadura há bastante tempo. Segundo dados de 2006, a reabilitação de edifícios residenciais consome aproximadamente $47 \%$ dos recursos do mercado de construção residencial e $36 \%$ de todo o setor da construção civil (Euroconstruct, 2006 apud Croitor e Melhado, 2009). Em países como Holanda e Inglaterra, a reabilitação de edifícios para habitação chega a aproximadamente $70 \%$ da produção imobiliária (Devecchi, 2010, p. 226).

As restritas experiências em programas de reabilitação de edifícios no Brasil evidenciam uma série de elementos determinantes na viabilização de projetos de habitação social em áreas centrais. Em 2001, a gestão municipal da cidade de São Paulo criou o Programa de Reabilitação da Área Central (Procentro) ${ }^{27}$ com 0 intuito de promover o desenvolvimento social e econômico da região central e de realizar a reabilitação urbanística e ambiental da área. À época do programa, o custo dos imóveis era mais atrativo do que os custos atuais, porém o problema, como coloca Alejandra Devecchi em entrevista, era o "[...] desconhecimento dos entraves e dificuldades técnicas, jurídicas e burocráticas para viabilizar as reformas". Para ela, as dificuldades técnicas relativas a obras e projetos de arquitetura e construção estão entre os principais fatores para a viabilização de projetos habitacionais nas áreas centrais.

No início do desenvolvimento do programa Procentro, havia uma grande dificuldade de se analisar a viabilidade das reformas e de se calcular os gastos necessários para a reabilitação dos edifícios. A prefeitura, então, estabeleceu um termo de cooperação técnica com especialistas franceses que apresentaram um método pelo qual era possível estabelecer rapidamente os gastos necessários para a reforma e as estratégias para realizá-la. "Em geral tínhamos cinco plantas que se repetiam em seu layout e em sua estrutura", coloca Devecchi. À época, a prefeitura criou o Gtai, Grupo Técnico de Avaliação de Imóveis, coordenador por Débora Sanches, que, após uma análise que envolveu 400 imóveis, selecionou 54 edifícios como adequados para reabilitação (Devecchi, 2010, p. 230).

Para a arquiteta, era necessário ter maior conhecimento sobre a questão da reforma. Muitos edifícios eram inviáveis para a reforma para fins habitacionais, e uma das causas principais era o aumento da sobrecarga devido à necessidade de instalação de caixas d'água maiores. No caso do centro de São Paulo, a maioria dos edifícios disponíveis é comercial, ${ }^{28}$ o que gera, como afirma Renata Milanesi, uma série de outras dificuldades relativas às necessidades de iluminação natural, ventilação e exigências do corpo de bombeiros. Para o professor Joel Felipe, o que mais afeta os projetos, no caso das reformas, são as exigências do corpo de bombeiros principalmente quanto à necessidade de criação de novas circulações verticais, que no passado não eram exigidas.

Além das questões relativas à avaliação dos edifícios e aos aspectos projetuais, a realização das obras de reabilitação colocam como outro elemento determinante no processo. Para Alejandra Devecchi, há carência de materiais e tecnologias específicas para realizar as reformas. A arquiteta coloca que materiais plug and 
play $^{29}$ e métodos mais precisos e menos invasivos, bastante comuns no mercado da construção civil europeu, são restritos no Brasil. Além disso, como coloca Milanesi, existe certa restrição por parte das construtoras que preferem o ganho de escala da construção de grandes conjuntos na periferia: "a reforma de um edifício dá mais trabalho e viabiliza poucas unidades".

Para os profissionais envolvidos na reabilitação dos edifícios, existe mais um elemento crítico que deve ser repensado nesse processo, a legislação relativa à construção. Em entrevista, o engenheiro Claudio Bernardes apontou que falta uma legislação específica para situações de retrofit, e a arquiteta Alejandra Devecchi disse que deveríamos pensar um novo código de obras para viabilizar as reformas. A preocupação dos dois profissionais parece consonante aos argumentos apresentados em recente debate no seminário Revitalização do Centro ${ }^{30}$ promovido pelo jornal Folha de S.Paulo. No evento, Nabil Bonduki, especialista em habitação social e ex-secretário de cultura do município, afirmou que a maioria dos edifícios do centro foi construída em uma época em que uma série de preocupações com segurança e acessibilidade não existia (Batista e Leite, 2017). No mesmo evento, a secretária municipal de desenvolvimento urbano ressaltou que pela primeira vez o novo código de obras do município possui elementos específicos para casos de reabilitação de edifícios. De fato, 0 atual Código de Obras, lei n. 16.642, de 9 de maio de 2017 (São Paulo, 2017), estabelece que, em edifícios construídos antes do ano de 1992 e em que a requalificação resolva as alterações de caráter estrutural do edifício, serão aceitas soluções alternativas às demais exigências vigentes, desde que não se comprometam os aspectos de salubridade, acessibilidade e segurança no uso da edificação.

\section{Vontade política e políticas públicas direcionadas}

Para Helena M. B. Silva, as experiências exitosas de habitação social em áreas centrais demonstram que é possível viabilizar os projetos tecnologicamente e monetariamente, mas que se deve haver grande vontade política para fazê-los. Débora Sanches afirma que, no período de 2001 a 2004, houve um grande empenho para viabilizar os projetos de habitação no centro, com mobilização nos diversos níveis da política pública. A arquiteta lembra que havia, entre outras coisas: trabalho das três esferas de governo; engajamento dos movimentos sociais apoiados por assessorias técnicas; posicionamento proativo dos técnicos da prefeitura e da Cohab com casos em que os eles chegavam a ir à casa dos proprietários dos imóveis para realizar a negociação; e o envolvimento do setor jurídico, pelo qual conseguiram, por exemplo, criar uma jurisprudência que separou o pavimento térreo do restante do edifício, deixando sob posse da prefeitura o pavimento térreo do edifício Hotel São Paulo, viabilizando o restante do edifício para o projeto habitacional.

Outro fator importante relacionado pelos entrevistados foi a necessidade da existência de políticas públicas específicas. 0 PAR Reforma, por exemplo, foi mencionado por Alejandra Devecchi e Helena M. B. Silva como uma experiência positiva no processo de reabilitação de imóveis para fins habitacionais na área central. Já, para a arquiteta Débora Sanches, ainda que grande parte dos projetos tenha sido realizada 
no âmbito do programa, este era inadequado para reformas e reabilitações: "Ele foi construído tendo como base o PAR e não dentro de uma lógica específica para reformas".

Helena M. B. Silva destacou que a experiência do PAR Reforma provocou mudanças até mesmo na lógica da produção habitacional com construtoras tradicionalmente voltadas para projetos de edifícios novos e, em maior escala, realizando obras de reforma. Renata Milanesi também exaltou o programa, colocando que, nesse processo, projetos interessantes haviam sido iniciados dentro da Cohab e da prefeitura e que muitos não evoluíram pelo fato de a gestão do projeto ficar nas mãos da Caixa Econômica Federal. A inexistência ou mesmo descontinuidade de políticas públicas também é um fator determinante. Para Milanesi, programas como o Morar no Centro, por exemplo, foram abandonados, e hoje não há mais uma política habitacional no município, somente uma meta de se construir 55 mil unidades. ${ }^{31}$ Para Joel Felipe, faltam vontade e coragem por parte dos dirigentes públicos do executivo, legislativo e judiciário de contrariar os interesses do mercado imobiliário. Para Felipe, os dirigentes beneficiam-se do mercado imobiliário e, por esse motivo, não os contrariam. Os raríssimos casos de efetiva aplicação dos instrumentos de controle dos processos de especulação urbana nos municípios brasileiros, como o caso do IPTU Progressivo, por exemplo, evidenciam os argumentos do professor. 0 posicionamento por parte do judiciário nos processos de desapropriação também vai ao encontro de sua visão sobre 0 assunto.

\section{Trabalho social e gestão condominial}

Não exclusivamente a projetos para áreas centrais, o trabalho social aparece como um dos fatores determinantes da viabilidade dos empreendimentos. Para Renata Milanesi, a demanda deve ser muito bem trabalhada, e o trabalho social constante. Para a arquiteta, a interrupção do trabalho social e o não envolvimento de movimentos sociais provocam muitos problemas e dificuldades no funcionamento dos conjuntos habitacionais. Para Helena M. B. Silva, os custos de condomínio e de conservação dos edifícios são muito altos para a população moradora dos edifícios e se tornam um dos fatores-chave a dificultar a viabilização dos projetos habitacionais em áreas centrais. Milanesi relata problemas graves de funcionamento de alguns conjuntos habitacionais do programa de locação social, quando o trabalho social não consegue ser muito efetivo e/ou a ocupação não foi previamente trabalha$\mathrm{da}$, como o caso de restrição de funcionamento do elevador por cobrança de pedágio para sua utilização.

Em ampla pesquisa sobre a questão da gestão condominial em edifícios de habitação social na cidade, Débora Sanches identificou que, entre as quatro formas de gestão existentes, ${ }^{32}$ a autogestão foi a que teve menor número de conflitos, menor valor de condomínio, menor inadimplência e menor número de problemas (Sanches, 2008, p. 201). Em sua dissertação, Sanches ressalta ser fundamental a realização do trabalho social da mobilização até a fase de pós-ocupação, para que a gestão condominial tenha sucesso. 


\section{Considerações finais}

Mesmo que a maior parte das propriedades do mundo seja modesta e não tenha sido financeirizada, sua progressiva transformação em ativos financeiros internacionais influenciará cada vez mais as possibilidades de acesso à moradia adequada nos grandes centros urbanos. Repensar a provisão habitacional de interesse social nas áreas centrais dos grandes centros urbanos nos parece uma importante tentativa de efetivação do direito à moradia adequada em um mundo em que 16 das 20 maiores metrópoles estão localizadas em países subdesenvolvidos (ONU, 2015). Para se efetivar a promoção de habitação de interesse social em áreas centrais, faz-se necessário que se consiga assegurar à propriedade urbana sua função social. Os processos de desapropriação para fins habitacionais, a cobrança de IPTU progressivo pelo não uso da propriedade e a formação de um banco de terras públicas são estratégias importantes para que possa fazer frente ao massivo capital imobiliário que sobrevaloriza os imóveis bem-localizados, tornando as áreas mais dotadas de infraestrutura inacessível para a maior parte dos cidadãos.

É urgente pensar políticas habitacionais que superem a ideologia da casa própria e os ditames do Banco Mundial, para que os governos se tornem meros facilitadores do processo de aquisição, financiamento e subsídios ao consumo do produto moradia (Rolnik, 2015, p. 79). Se o objetivo é garantir o direito à moradia e à cidade, devemos promover outras formas de propriedade que não a privada e individual. Como coloca Maricato (2000, p. 15) se a própria classe média tem dificuldades de acesso ao mercado residencial privado, a população de baixa renda dificilmente conseguirá reter o imóvel.

Considera-se necessário pensar a moradia como um serviço social, ${ }^{33}$ com distintas formas de acesso, de propriedade, de financiamento, de subsídio, etc. Isto envolve o desenvolvimento de políticas públicas que contemplem a inserção da moradia no território, com acesso à oferta de empregos e serviços, levando-se em conta, ainda, os custos condominiais, as relações sociais, etc. $E$, para o desenvolvimento de uma política pública nesses moldes, faz-se necessário pensar formas de gestão menos centralizada, com estruturas de maior capilaridade, que possam estar inseridas nas lógicas locais, assim com acontece em países como França e Inglaterra, por exemplo. A construção de um amplo parque habitacional de interesse social nas áreas centrais, que seja destinado aos usuários através de procedimentos, tais como a locação social, o usufruto vitalício e formas associativas de propriedade, deve ser uma das diversas iniciativas de uma política pública estrutural.

Para a reabilitação de áreas centrais com habitação para população de baixa renda, é necessário viabilizar políticas públicas e preparar legislações específicas que facilitem e incentivem a reforma das edificações para fins sociais. 0 Estado pode ter um importante papel como promotor desse processo, o que ajudaria a alavancar o desenvolvimento de uma área importante da indústria da construção civil no Brasil. Esse desenvolvimento possibilitaria reduzir os custos e os tempos de reforma, o que contribuiria para viabilizar um maior número de projetos de habitação de interesse social nos centros históricos. 
Quanto aos processos de desapropriação, considera-se que o Estado, pela possibilidade de criação de nova matrícula para o imóvel e de resolução das longas cadeias dominiais, poderia ser um agente facilitador. Há que se conseguir superar o descumprimento da função social da propriedade e os processos de supervalorização dos imóveis, que hoje dificultam sobremaneira os processos de desapropriação. 0 acesso à habitação formal para população de baixa renda nas áreas centrais das metrópoles brasileiras é muito promissor, quando se leva em conta a perspectiva de efetivação do direito à moradia e do direito à cidade - considera-se fundamental avançar para superação das dificuldades identificadas. Quando se analisam os casos em que foi possível a produção, não se encontra um único conjunto de fatores que tornou viável a sua concretização. As especificidades de cada projeto, situação, local, momento e do papel de cada um dos atores envolvidos no processo dificultam a definição de uma única forma para a viabilização de projetos de habitação social em área central. As entrevistas, dados e reflexões aqui apresentados buscam, porém, arrolar e analisar os fatores que estão envolvidos nesse processo.

A região central da cidade de São Paulo concentrava, em 2015, 17,8\% dos empregos formais do município ${ }^{34}$ e apenas $3,8 \%$ de seus habitantes (IBGE, 2011). Eram 911.360 empregos formais para uma região em que habitavam 431.106 pessoas. Ainda que na década de 2000 a vacância na área central tenha se reduzido de $24,7 \%$ para $9,5 \%$, ainda existiam, no ano de 2010, 19.744 domicílios particulares permanentes vagos (ibid.). 0 preço do metro quadro do imóvel, na área central da cidade de São Paulo, subiu 189\% na década de 2000, e, em 2015, o ônus excessivo com aluguel atingiu, pela primeira vez, valores superiores a $50 \%$ do componente do déficit habitacional (Fundação João Pinheiro, 2018). Se não for possível intensificar as políticas públicas de cumprimento da função social da propriedade, do direito à moradia e do direito à cidade, as metrópoles poderão se tornar "cidades ocas", inacessíveis para a moradia da maioria de seus habitantes.

\section{[I] https://orcid.org/0000-0001-6899-6914}

Universidade Federal do ABC, Programa de Planejamento e Gestão do Território. Santo André, SP/ Brasil.

ulisses.terra@ufabc.edu.br

\section{[II] https://orcid.org/0000-0002-3807-4684}

Universidade Federal do ABC, Programa de Planejamento e Gestão do Território. Santo André, SP/ Brasil.

Universidade Federal do Rio Grande do Norte, Departamento de Arquitetura. Natal, RN/Brasil. ricardo.moretti@ufabc.edu.br 


\section{Notas}

(1) O distrito da Barra Funda recebeu 3.198 novos apartamentos e um incremento populacional de 2.680 habitantes. No distrito de Vila Mariana, foram 9.820 novos apartamentos e um incremento populacional de 6.801 habitantes.

(2) Dados de 2015 de levantamento realizado pela Savills, uma das maiores empresas do setor imobiliário do mundo. Disponível em: http://www.savills.co.uk/insight-and-opinion/savills-news/198559-0/ world-real-estate-accounts-for-60--of-all-mainstream-assets. Acesso em: 2 abr 2018.

(3) Em 2009, o G20, em uma das ações pós-crise de 2008, solicitou que o Bank for International Settlements produzisse e publicasse, a partir de dados oficiais de mais de 50 países, os preços dos imóveis residenciais no mundo. Após a crise do subprime, os preços dos imóveis passaram a ser considerados indicadores-chave dos riscos de estabilidade financeira global (Scatigna, Szemere e Tsatsaronis, 2014).

(4) As dez mais populosas regiões metropolitanas do País - São Paulo, Rio de Janeiro, Belo Horizonte, Porto Alegre, Recife, Fortaleza, Salvador, Curitiba, Campinas e Belém - concentravam, em 2010, mais de 59 milhões de habitantes ( $31,3 \%$ da população) com um PIB a preços correntes de 1,618 trilhão de reais (IBGE, 2012).

(5) Aglomerados subnormais é uma classificação do IBGE para um conjunto constituído por 51 ou mais unidades habitacionais caracterizadas por ausência de título de propriedade e pelo menos uma das seguintes características: irregularidade das vias de circulação e do tamanho e forma dos lotes e/ou carência de serviços públicos essenciais, como coleta de lixo, rede de esgoto, rede de água, energia elétrica e iluminação pública (IBGE, 2012).

(6) Jornal O Estado de S.Paulo, de 13 ago 2016. Disponível em: https://www.estadao.com.br/noticias/ geral,1-dos-donos-de-imoveis-concentra-45-do-valor-imobiliario-de-sao-paulo,10000069287. Acesso em: 10 out 2017.

(7) O Programa Minha Casa Minha Vida do governo federal divide a forma de atendimento habitacional em faixas de renda familiar: Faixa 1 - Famílias com renda mensal bruta de até $\mathrm{R} \$ 1.600,00$; Faixa 2 - Famílias com renda mensal bruta de até $\mathrm{R} \$ 3.275,00$; Faixa 3 - Famílias com renda mensal bruta acima de $\mathrm{R} \$ 3.275,00$ até $\mathrm{R} \$ 5$ mil. Estimativa da Fundação João Pinheiro (2016) revela que, no ano de 2014, 83,9\% do total do déficit habitacional urbano no Brasil estava concentrado na faixa de rendimento familiar de até três salários mínimos. O déficit habitacional concentra-se, portanto, dentro da faixa 1 do PMCMV.

(8) Iniciada em 16 de junho de 2011 (lei federal n. 12.424).

(9) A distância aqui é definida por uma linha reta hipotética entre a centralidade e o empreendimento.

(10) O estudo definiu duas centralidades como mais importantes para a análise: a praça da Sé, como centro histórico da cidade, e avenida Berrini, como atual centro de negócios (Marques e Rodrigues, 2013).

(11) As atualizações foram feitas a partir de diversas fontes: publicações jornalísticas, Diário Oficial do Município, artigos científicos, sites das secretárias de habitação, etc.

(12) Estimativa realizada pelo Instituto de Pesquisa Econômica Aplicada (Ipea) para o ano de 2012 com base na pesquisa IBGE/Pnad. 
(13) As entrevistas ocorreram nos anos de 2015 e 2016 e abordaram sete especialistas no tema: Claudio Bernardes, engenheiro civil e empresário do setor da construção civil; Benedito Roberto Barbosa, advogado do Centro Gaspar Garcia de Direitos Humanos, entidade ligada à defesa dos direitos humanos e à construção de políticas públicas; Renata Milanesi, arquiteta da Companhia Metropolitana de Habitação de São Paulo; Alejandra Devecchi, arquiteta urbanista e ex-coordenadora do projeto Nova Luz; Débora Sanches, arquiteta, professora universitária e coordenadora do GTAI (Grupo Técnico de Análise de Imóveis) no Procentro, Sehab de 2002 a 2004; Helena Menna Barreto Silva, pesquisadora associada ao Labhab/FAU-USP e excoordenadora do programa Morar no Centro; e Joel Pereira Felipe, arquiteto, professor da Universidade Federal do Sul da Bahia.

(14) O PAR - Programa de Arrendamento Residencial - foi um programa federal criado em 1999 e operado pela Caixa Econômica Federal (CEF), que tinha como objetivos aquisição, construção e reforma de unidades residências para fins de arrendamento residencial, com opção de compra ao final do prazo contratado. No momento de consolidação do programa em âmbito federal, os movimentos sociais mobilizaram-se e iniciaram uma série de negociações junto à CEF com o objetivo de flexibilizar o Programa e criar uma nova modalidade que possibilitasse a reforma de edifícios em áreas centrais (Maleronka, 2005). Após uma série de reuniões e tratativas, foi criada a modalidade PAR Reforma, com o objetivo de reabilitar edifícios obsoletos nas áreas centrais dos municípios.

(15) O Sindicato das Empresas de Compra, Venda, Locação e Administração de Imóveis Residenciais e Comerciais de São Paulo, também denominado Sindicato da Habitação, congrega mais de 90 mil empresas do setor de construção civil do estado de São Paulo.

(16) Sem entrar no mérito sobre a definição de centro e centralidade urbana, utilizaremos como referência de centro para a cidade de São Paulo a região sob administração da subprefeitura da Sé formada pelos distritos da Bela Vista, Bom Retiro, Cambuci, Consolação, Liberdade, República, Sé e Santa Cecília.

(17) O SFH conta com recursos do SBPE (Sistema Brasileiro de Poupança e Empréstimo) e do FGTS (Fundo de Garantia por Tempo de Serviço).

(18) A construtora Vitacon anunciou, em 2017, o lançamento do projeto de um edifício na região central com apartamentos de $10 \mathrm{~m}^{2}$. Em 2015, a construtora já havia anunciado a construção em um edifício com apartamentos de $14 \mathrm{~m}^{2}$ (Folha de S. Paulo, 2017).

(19) A Secretaria Municipal de Desenvolvimento Urbano (SMDU) utiliza o Cadastro Territorial e Predial, de Conservação e Limpeza (TPCL) - cadastro de base fiscal mantido pelo Departamento de Arrecadação e Cobrança - para o desenvolvimento de um relatório anual da evolução do uso do solo urbano do município com valores de uso e classificação do tipo de imóvel cadastrado (Schevz e Paulino, 2015).

(20) O Programa Minha Casa Minha Vida (PMCMV) do governo federal entregou 2,6 milhões de unidades habitacionais das mais de 4,2 milhões contratadas desde seu lançamento em março de 2009 (Portal Brasil, 2016). É o maior programa de produção habitacional do País desde a extinção do Banco Nacional de Habitação (BNH). O programa foi capaz de gerar empregos e movimentar a cadeia produtiva da construção, mas recebeu inúmeras críticas de especialistas do assunto por desconsiderar uma série de elementos relativos à política urbana e habitacional. Muitas publicações avaliam o Programa dentre as quais recomendamos o livro Minha Casa... E a Cidade? Avaliação do Programa Minha Casa Minha Vida em seis estados brasileiros?, disponível para download no portal eletrônico do Observatório das Metrópoles (www. observatoriodasmetropoles.net). 
(21) O Programa Casa Paulista do governo do Estado de São Paulo, criado em setembro de 2011, tem como função fomentar a política de habitação social do governo do estado. Entre seus principais objetivos está o de "[...]mobilizar a iniciativa privada, agentes públicos de todas as esferas, associações e cooperativas habitacionais e sindicatos para a produção de moradias de interesse social" (São Paulo, 2011).

(22) Estatísticas do índice Fipezap, disponível em: http://www.zap.com.br/imoveis/fipe-zap/.

(23) O chamado quadrante sudoeste é a mais privilegiada área da metrópole paulistana. Concentrou, nas últimas décadas os maiores investimentos públicos e privados da cidade de São Paulo e é a região que, como coloca o professor Flávio Villaça, apresenta a "tripla segregação dos mais ricos", com suas moradias, seus empregos e seu comércio e serviços (Villaça, 2011).

(24) Cadeia dominial é basicamente a relação de proprietários de determinado imóvel da titulação inicial junto ao poder público até o atual proprietário.

(25) Durante a gestão municipal do período de 2001 a 2004, a prefeitura criou um programa coordenado pela Secretaria de Habitação que tinha como objetivo a promoção do acesso à moradia na área central, tendo como diretrizes priorizar a reforma de prédios vazios, combinar soluções habitacionais com iniciativas de geração de rendas e buscar a diversidade social nos bairros centrais. O plano envolvia uma área aproximada de $52 \mathrm{Km}^{2}$ e 13 distritos: Brás, Cambuci, Liberdade, Barra Funda, Bela Vista, Consolação, Santa Cecília, Bom Retiro, Pari, Belém, Sé, República e Mooca.

(26) Em 2015 o governo federal editou a medida provisória n. 700 com grandes alterações nas disposições legais sobre os processos de desapropriação por interesse público. A MP foi fortemente criticada por especialista e, não sendo votada nem no Senado nem na Câmara, perdeu a vigência em maio de 2016 (Agência Senado, 2016).

(27) O Procentro teve financiamento do BID e possuía como perímetro de intervenções os distritos da Sé e da República.

(28) Pesquisa concluída em 2008, sob coordenação da professora Helena Menna Barreto Silva, apontava um universo de 158 edifícios verticais com andares superiores vazios. Destes, 69 estavam totalmente desocupados, sendo 39 comerciais, 16 hotéis, 7 de uso misto e 7 residenciais. Pesquisa realizada por Alejandra Devecchi, em dezembro de 2008, constatou 175 edifícios vazios em um universo de 354 imóveis com algum grau de subutilização. Nessa pesquisa, a maioria dos edifícios vagos era não residencial (Devecchi, 2010, p. 121). Renata Milanesi relata, em entrevista, que um cuidadoso levantamento realizado pela Cohab, no ano de 2009, conjuntamente com a Fupam, revelou que a maioria dos imóveis vazios no centro era comercial.

(29) O termo plug and play refere-se, aqui, a uma série de materiais para construção pensados para serem instalados e usados rapidamente. Vão de kits de iluminação led a módulos de banheiros inteiros que chegam prontos para serem instalados dentro do edifício.

(30) Nos dias 19 e 20 de setembro de 2017, a Folha de S.Paulo organizou o Fórum Revitalização do Centro, com a realização de mesas de debates que abordaram diversos aspectos relacionados ao centro da cidade. 
(31) No Programa de Metas da gestão municipal 2013-2016, estavam previstas a construção de 55 mil unidades habitacionais. Apesar das críticas e pressão dos movimentos sociais e de uma série de urbanistas à época da entrevista feita a arquiteta Renata Milanesi, a secretaria municipal de habitação estava na cota do Partido Progressista que indicou o engenheiro e empresário do setor imobiliário José Floriano de Azevedo como secretário.

(32) Gestão dos condomínios realizada pelo poder público (Cohab), por administradora com e sem síndico e por autogestão.

(33) A resolução recomendada n. 75, de 2 de julho de 2009 (Balbim, 2015) coloca, entre os objetivos do Serviço de Moradia Social: viabilizar solução de moradia para baixa renda em áreas urbanas centrais; o combate ao mercado informal de aluguel (cortiços e favelas); a redução do número de imóveis vazios e subutilizados; a reabilitação de edifícios, otimizando o uso do estoque edificado existente; e o combate à expansão urbana periférica. Quanto aos princípios do Serviço de Moradia Social que o diferencia das demais políticas habitacionais no País, estão o de garantir: o direito à moradia digna e integrada à cidade; o cumprimento da função social da propriedade e da cidade; e a oferta de moradia como serviço público permanente, orientado às características do beneficiário.

(34) Os dados relativos a emprego são de 2015 da Fundação Seade (2017), e os dados populacionais relativos ao ano de 2010 do Censo Demográfico do IBGE (2011).

\section{Referências}

ADORNO, L. (2017). Donos aceitam oferta da prefeitura, e prédio ocupado em SP deve virar moradia popular. Disponível em: https://noticias.uol.com.br/cotidiano/ultimasnoticias/2017/11/18/ donos-de-predio-ocupado-em-sp-aceitam-proposta-da-prefeitura-e-local-deve-sermoradiapopular.htm. Acesso em: 12 dez 2017.

AGÊNCIA SENADO (2016). MP da desapropriação entrega as cidades aos interesses privados, dizem debatedores. Distrito Federal: 12/4/2016. Disponível em: https://www12.senado.leg.br/noticias/ materias/2016/04/12/mp-da-desapropriacao-entrega-as-cidades-aos-interesses-privadosdizem-debatedores. Acesso em: 10 dez 2017.

AMÂNCIO, T. e MARIANI, D. (2018). Quase metade dos prédios de SP são de antes das regras duras antiincêndio. Folha de S.Paulo. Disponível em: https://www1.folha.uol.com.br/cotidiano/2018/05/ quase-metade-dos-predios-de-sp-sao-anteriores-as-regras-duras-anti-incendio.shtml. Acesso em: 22 maio 2018.

BALBIM, R. (2015). Serviço de Moradia Social ou Locação Social: alternativas à política habitacional. Brasília, Ipea. Disponível em: http://www.ipea.gov.br/portal/index.php?option=com_content \&view=article\&id=26335. Acesso em: 15 jul 2017.

BANCO MUNDIAL (1993). Housing Enabling Markets to Work. Washington-DC, Banco Mundial. Disponível em: http://documents.worldbank.org/curated/pt/387041468345854972/ Housingenabling-markets-to-work. Acesso em: 10 ago 2017. 
BARBOSA, B. R. (2014). Protagonismo dos movimentos de moradia no centro de São Paulo: trajetória, lutas e influencias nas políticas habitacionais. Dissertação de Mestrado. Santo André, Universidade Federal do ABC. Disponível em https://sites.google.com/site/pospgt2/beneditoroberto-barbosa. Acesso em: 10 jan 2018.

BATISTA, E. L. e LEITE, L. (2017). Para especialistas, lei trava reforma de prédio antigo no centro. Disponível em: http://www1.folha.uol.com.br/seminariosfolha/ 2017/09/1920900-paraespecialistas-lei-trava-reforma-de-predio-antigo-no-centro.shtml. Acesso em: 10 out 2017.

BOMFIM, V. C. (2004). O Centro Histórico de São Paulo: a vacância imobiliária, as ocupações e os processos de reabilitação urbana. Cadernos Metrópole. São Paulo, n. 12. Disponível em: https:// revistas.pucsp.br/index.php/metropole/article/download/8808/6529. Acesso em: 10 nov 2017.

BONATES, M. F. (2009). Política de habitação nas áreas centrais: retórica versus prática. São Paulo, Cadernos Metrópole. São Paulo, n. 21. Disponível em: https://revistas.pucsp.br/index.php/ metropole/article/view/5958. Acesso em: 22 fev 2017.

CRERAR, P. e PRYNN, J. (2015). Revealed: Howforeignbuyershavebought 1100 bn of London property in sixyears. Londres, 21 out. Disponível em https://www.standard.co.uk/news/london/revealedhow-foreign-buyers-have-bought-100bn-of-london-property-in-six-years-a3095936.html. Acesso em: 12 nov 2017.

CROITOR, E. P. N. e MELHADO, S. (2009). A gestão de projetos aplicada à reabilitação de edifícios: estudo da interface entre projeto e obra. São Paulo, EPUSP. Disponível em: http://www.pcc.usp. br/files/text/publications/BT_00529.pdf. Acesso em: 10 nov 2017.

DEVECCHI, A. M. (2010). Reformar não é construir. A reabilitação de edifícios verticais: novas formas de morar em São Paulo no século XXI. Tese de Doutorado. São Paulo, Universidade de São Paulo.

FELITTI, C. e CORREA, V. (2015). Centro de SP tem queda de 70\% no número de apartamentos vazios. Disponível em: http://www1.folha.uol.com.br/saopaulo/2015/02/1592340-centro-de-sp-temqueda-de-70-no-numero-deapartamentos-vazios.shtml. Acesso em: 15 jan 2018.

FOLHA DE S.PAULO (2017). Centro de São Paulo terá apartamento de 10 metros quadrados por R\$ 100 mil. Folha de S.Paulo, 16/8. Disponível em: https://www1.folha.uol.com.br/sobretudo/ morar/2017/08/1910409-centro-de-sao-paulo-tera-apartamento-de-10-metros-quadradospor-r-100-mil.shtml . Acesso em: 10 fev 2018.

FUNDAÇÃO JOÃO PINHEIRO (2018). Déficit Habitacional no Brasil 2015. Disponível em: http://fjp. mg.gov.br/index.php/docman/direi-2018/785-serie-estatistica-e-informacoes-n06-deficithabitacional-no-brasil-2015/file. Acesso em: 30 abr 2018.

FUNDAÇÃO SEADE (2017). Município de São Paulo e o mercado de trabalho. Disponível em: http:// www.seade.gov.br/produtos/midia/2017/01/MSP_Indicadores_25jan_2.pdf. Acesso em: 15 nov 2017.

GATTI, S. (2015). O programa de Locação Social em SP: uma revisão necessária. ObservaSP. Disponível em: https://observasp.wordpress.com/2015 /06/22/o-programa-de-locacao-social-em-sp-umarevisaonecessaria/. Acesso em: 15 fev 2016.

IBGE (2003). Censo Demográfico 2000. Agregados por Setores Censitários. Disponível em: https:// www.ibge.gov.br/estatisticas-novoportal/sociais/saude/9663-censo-demografico-2000. html?edicao=10192\&t=sobre. Acesso em: 27 out 2017. 
IBGE (2011). Censo Demográfico 2010. Resultados da Sinopse por setor censitário. Rio de Janeiro. Disponível em: http://www.censo2010.ibge.gov.br. Acesso em: 27 out 2017.

(2012). Censo Demográfico 2010. Resultados da Sinopse por setor censitário. Disponível em: http://www.censo2010.ibge.gov.br. Acesso em: 27 out 2017.

IPEA (2013). Estimativas do déficit habitacional brasileiro (PNAD 2007-2012). Disponível em: http:// repositorio.ipea.gov.br/bitstream/11058/5668/1/NT_n05_estimativas.pdf. Acesso em: 10 nov 2017.

KOHARA, L. COMARU, F. e FERRO, M. C. (2015). Pela retomada dos programas de locação social. Disponível em: https://observasp.wordpress.com/2015/04/22/pela-retomada-dos-programasdelocacao-social/. Acesso em: 14 mar 2016.

LEITE, R. P. e GONÇALVES, F. M. (2010). Morar no centro: discurso e prática. Disponível em: http:// www.prefeitura.sp.gov.br/cidade/secretarias/upload/ chamadas/artigo_morar_no_centro_ ricardo_leite_1290625875.pdf. Acesso em: 12 jan 2018.

LIMA NETO, V. C.; KRAUSE, C. e FURTADO, B. A. (2015). O Déficit habitacional intrametropolitano e a localização de empreendimentos do programa Minha Casa Minha Vida: mensurando possibilidades de atendimento. Rio de Janeiro, Ipea. Disponível em: http://www.ipea.gov.br/ portal/index.php?option=com_content\&view=article\&id=24563:td-2044-o-deficithabitacionalintrametropolitano-e-a-localizacao-de-empreendimentos-do-programa-minha-casa-minhavidamensurando-possibilidades-de-atendimento\&catid=344:2015\&directory=1. Acesso em: 10 out 2017.

LINKE, C.; SERRA, B.; GARREFA, F.; ARAUJO, D. C.; VILLA, S. B.; NADALIN, V. G. e KRAUSE, C. H. (2016). Inserção Urbana de Habitação de Interesse Social: um olhar sobre mobilidade cotidiana e uso do solo. Brasília, Ipea. Disponível em: http://www.ipea.gov.br/agencia/images/stories/PDFs/livros/ livros/160905_livro_cidade_movimento_cap12.pdf. Acesso em: 28 fev 2018.

MARICATO, E. (2001). Habitação social em áreas centrais. Campinas, Revista Oculum Ensaios, FAU/ PucCamp, n. 1, pp. 13-24. Disponível em: http://periodicos.puc-campinas.edu.br/seer/index. php/oculum/article/view/1744/1685. Acesso em: 10 out 2016.

MARICATO, E. et al. (2001). Preço de desapropriação de terras: limites as políticas públicas nas áreas de habitação, meio ambiente e vias públicas em São Paulo. São Paulo, Lincoln InstituteResearchReport e Laboratório de Habitação e Assentamentos Humanos da FAUUSP. Disponível em: http://labhab. fau.usp.br/biblioteca/produtos/relatorio_preco_desaprop.pdf. Acesso em: 3 jan 2018.

MARQUES, E. e RODRIGUES, L. (2013). O programa Minha Casa Minha Vida na metrópole paulistana: atendimento habitacional e padrões de segregação. Revista Brasileira de Estudos Urbanos e Regionais, v. 15, n. 2, pp. 159-177. Disponível em: http://rbeur.anpur.org.br/rbeur/article/ view/4740. Acesso em: 28 fev 2018.

NADALIN, V. G. (2010). Três ensaios sobre economia urbana e mercado de habitação em São Paulo. Tese de doutorado. São Paulo, Universidade de São Paulo. Disponível em: http://www.teses.usp. br/teses/disponiveis/12/12138/tde-10052010-140932/en.php. Acesso em: 10 maio 2017.

NADALIN, V. G.; KRAUSE, C. e LIMA NETO, V. C. (2016). “Distribuição de aglomerados subnormais na rede urbana e nas grandes regiões brasileiras". In: MORAIS, M. P.; KRAUSE, C. e LIMA NETO, V. C. (orgs.). Caracterização e tipologia de assentamentos precários: estudos de caso brasileiros. Brasília, Ipea. Disponível em: http://www.ipea.gov.br/agencia/images/stories/PDFs/livros/ livros/160718_caracterizacao_tipologia.pdf. Acesso em: 5 fev 2018. 
NAKAGAWA, F. (2014). Valorização de imóvel no Brasil foi a maior do mundo nos últimos 5 anos. O Estado de S.Paulo, 17 jan. Disponível em: http://economia.estadao.com.br/noticias/ geral,valorizacao-de-imovel-no-brasil-foi-a-maior-do-mundo-nos-ultimos-5-anos, 175663 e. Acesso em: 12 dez 2017.

NAKANO, A. K. (2015). Elementos demográficos sobre a densidade urbana da produção imobiliária: São Paulo, uma cidade oca? Tese de doutorado. Campinas, Universidade Estadual de Campinas.

ONU (2015). World Urbanization Prospects: The 2014 Revision. Disponivel em: https://esa.un.org/ unpd/wup/Publications/Files/WUP2014-Report.pdf. Acesso em: 7 jul 2017.

OSBORNE, H. e RAWLINSON, K. (2017). Empty homes: normal rules do notapplytosuper-rich in London. The Guardian, 1ㅇao. Disponível em: https://www.theguardian.com/society/2017/aug/01/ empty-homes-normal-rules-do-not-apply-to-super-rich-in-london. Acesso em: 12 nov 2017.

PETTIFOR, A. (2018). Whybuilding more homes willnot solve Britain'shousingcrisis. Disponível em: https://www.theguardian.com/commentisfree/2018/jan/27/building-homes-britain-housingcrisis. Acesso em: 10 fev 2018.

PINA, R. (2018). Necessidade habitacional impacta a vida de 1,2 milhão de famílias em São Paulo. Disponível em: https://www.brasildefato.com.br/2018/05/29/necessidade-habitacionalimpacta-a-vida-de-de-12-milhao-de-familias-em-sao-paulo/. Acesso em: 29 maio 2018.

PORTAL BRASIL (2016). Fundação Palmares certifica 29 comunidades quilombolas. Disponível em: http://www.brasil.gov.br/cidadania-e-justica/2017/01/fundacao-palmares-certifica-29comunidades-quilombolas. Acesso em: 19 set 2017.

PREFEITURA DE SÃO PAULO (2009). População nos anos de levantamento censitário: município de São Paulo, subprefeituras e distritos municipais. Disponível em: http://smul.prefeitura.sp.gov.br/ historico_demografico/tabelas/pop_dist.php. Acesso em: 5 out 2016.

ROLNIK, R. (2015). Guerra dos lugares: a colonização da terra e da moradia na era das finanças. São Paulo, Boitempo.

SANCHES, D. (2008). Gestão condominial de habitação de interesse social: estudo na área central de São Paulo. Dissertação de Mestrado. São Paulo, Instituto de Pesquisas Tecnológica - IPT. Disponível em: http://gaspargarcia.org.br/wp-content/uploads/2015/02/ GestaoCondominialDeHabitacaoDeInteresseSocial-1.pdf. Acesso em: 12 out 2016.

SANTO AMORE, C.; SHIMBO, L. Z. e RUFINO, M. B. C. (orgs.). (2015). Minha Casa... E a cidade? Avaliação do Programa Minha Casa Minha Vida em Seis Estados Brasileiros. Rio de Janeiro, Letra Capital, Observatório das Metrópoles. Disponível em: http://www.observatoriodasmetropoles. net/index.php?option=com_abook \&view=book\&catid=1\%3Alivros\&id=154\%3Aminha-casa-eacidade\&ltemid=123\&lang=pt. Acesso em: 15 ago 2016.

SÃO PAULO - Estado (2011). Agência Paulista de Habitação Social. Portas abertas para o desenvolvimento habitacional. Portal do Governo, 5/12. Disponível em: http://www.saopaulo.sp.gov.br/spnoticias/ ultimas-noticias/agencia-paulista-de-habitacao-social/. Acesso em: 1ㅇ fev 2019.

SÃO PAULO. Prefeitura Municipal (2017). Lei municipal n. 16.642, de 9 de maio de 2017. Aprova o Código de Obras e Edificações do Município de São Paulo. Disponível em: https://leismunicipais. com.br/codigo-de-obras-sao-paulo-sp. Acesso em: $10 \mathrm{dez} 2017$. 
SASSEN, S. (2016). Seminário internacional Cidades e Territórios: Encontros e Fronteiras na Busca da Equidade - São Paulo, 14 jun. Conferência SaskiaSassen. Disponível em: https://www.youtube. com/watch?v=butebn7Ub7E. Acesso em: 10 nov 2016.

(2017). The City: A CollectiveGood? The brown journal of world affairs, v. XXIII, issue II. Disponível em: http://saskiasassen.com//PDFs/BrownJnI2017\%20City\%20Colectv\%20good\%20 copy.pdf. Acesso em: 10 fev 2018.

SCATIGNA, M., SZEMERE, R. e TSATSARONIS, K. (2014). Residential property price statistics across the globe. BIS Quarterly Review, september, pp. 61-76. Disponível em: https://www.bis.org/publ/ qtrpdf/r_qt1409h.htm. Acesso em: 5 out 2017.

SCHEVZ, L. L. e PAULINO, M. I. R. (2015). Evolução do Uso do Solo Urbano. São Paulo: Secretaria Municipal de Desenvolvimento Urbano/SMDU. Departamento de Produção e Análise de Informação/ Deinfo. Disponível em: http://infocidade.prefeitura.sp.gov.br/index.php?sub=notas\&cat=17. Acesso em: 10 dez 2017.

SHIMBO, L. (2013). O aquecimento imobiliário e o mercado de habitação na área central de São Paulo (2001-2010). EURE. Santiago, v. 39, n. 117. Disponível em: https://scielo.conicyt.cl/scielo. php?script=sci_arttext\&pid=S0250-71612013000200010. Acesso em: 25 fev 2018.

SILVA, H. M. B. (coords.). (2007). Oportunidades e limites para a produção de habitação social no centro de São Paulo. Lincoln Institute of Land Policy. Disponível em: http://fau.usp.br/depprojeto/ labhab/biblioteca/textos/silva_oportlimites_prodha bsocial.pdf. Acesso em: 10 out 2016.

SOUZA, R. V. (2017). Questão de moradia: ocupações como experiência autogestionária. Cadernos NAUI, v. 6, n. 10. Disponível em: https://repositorio.ufsc.br/handle/123456789/181282?show=full. Acesso em: 10 out 2017.

VILLAÇA, F. (2011). São Paulo: segregação urbana e desigualdade. Estudos Avançados. São Paulo, v. 25, n. 71, pp. 37-58. Disponível em:<http://www.scielo.br/scielo.php?script=sci_arttext\&pid=S010340142011000100004\&lng=en\&nrm=iso>. Acesso em: 10 dez 2017.

Texto recebido em 10/jun/2018 Texto aprovado em 12/jul/2018 